\title{
A Review of Land Use Land Cover Change in The Catchment Area of Musi Hydropower Plant in Bengkulu Province
}

\author{
Sukisno ${ }^{1,2 *}$, Widiatmaka ${ }^{3}$, Januar J. Purwanto ${ }^{4}$, Bambang Pramudya $\mathrm{N}^{5}$, Khursatul \\ Munibah $^{3}$ \\ ${ }^{1}$ Graduate Student of Natural Resources and Environmental Management IPB University, Bogor, West \\ Java, Indonesia \\ ${ }^{2}$ Dept. of Agriculture Cultivation, Faculty of Agriculture, University of Bengkulu, Bengkulu, Indonesia \\ ${ }^{3}$ Dept. of Soil Science and Land Resources, IPB University, Bogor, West Java, Indonesia \\ ${ }^{4}$ Dept. of Civil and Environment, IPB University, Bogor, West Java, Indonesia \\ ${ }^{5}$ Dept. of Agricultural and Bio-system Engineering IPB University, Bogor, West Java, Indonesia
}

\begin{abstract}
This research was conducted to review land use land cover change in the catchment area of Musi Hydropower Plant in Bengkulu Province. The data used in this research is land use land cover map year 2000 to 2018 from Ministry of Environment and Forestry of the Republic of Indonesia. The analyse was done by overlaying time series map of land use land cover map from 2000 to 2018 on the map of forest area. The result shows that primary dryland forest degradated significantly, around 568 ha less than 20 years. In the other side, settlements and built-up area significantly increase, 1.331 ha in 20 years. Meanwhile, the land use of agricultural dry land mixed with shrubs, in agregat decreased by 1.078 ha. The area of agricultural dry land mixed with shrubs was increase during period of 2000 to 2014, and then slightly decrease in the period of 2014 to 2018. Land use changes on the catchment area have negative impact on the quality of environmental services, such as erosion and sedimentation on the reservoir of Musi Hydropower Plant. Intervention needed to reduce the negative impact of the land use change on ecosystem services.
\end{abstract}

Key words: land use land cover change, forest degradation, catchment area, Musi Hydropower Plant

\section{Introduction}

Increasing population followed by the growing of demand for land. Land is the stage on which all human activity is being conducted and the source of the materials needed for this conduct. The competition for land is increasing as demand for multiple land uses and

*Corresponding author: sukisno@unib.ac.id 
ecosystem [1, 2, 3, 4]. Land resources, as sources and sink of human activity, have limited availability and capability. Land use land cover competition result in land use land cover changes.

Land use land cover changes have positive and negative effects. The development of technology, improvement the qua lity of environment, increasing environmental services and improvement of human welfare are the positive impacts of land use land cover changes. However, at times land use land cover changes have detrimental impacts. Deforestation by a gricultural expansion, expansion of settlements a rea from a gricultural land, carbon losses, soil erosion, sedimentation, floods, and losses of biodiversity are the negative impacts of land use land cover changes $[5,6,7]$.

Sub Watershed of Musi Hulu is an area in Bengkulu Province, Indonesia, that have high magnitude of land use land cover changes. In 2006, Musi Hydropower Plant use the water from Musi River to generate the power plant. Sub Watershed of Musi Hulu as the catchment area of Musi Hydropower Plant. With the time of operation around ten years, in 2014, sedimentation in the reservoir of Musi Hydropower Plant has been interfered the water supply to the power plant $[8,9]$. Musi Hydropower Plant must dredge the sediment in the reservoir.

Sedimentation in a reservoir is an impact of soil erosion on the catchment a rea [10]. Soil erosion and associated increases in sediment mobilization and transport have long been recognized as a major problem in those regions where erosion rates and suspended sediment yields are high [11]. Soil erosion highly correlated with land use land cover changes [5]. Land use land cover changes from forest to agricultural activity and from agricultural land to settlement areas will followed by increasing erosion rates and suspended sediment yields.

Land use land cover change is a dynamic process and deals with land development. The assessment of the driving forces behind land use land cover change is necessary when analyzing and explaining past patterns, as well as when aiming to forecast future patterns [2, 4]. Researchers and professionals used land use land cover change models to explore the dynamics and drivers of land use land cover change and to inform policies affecting such change $[12,13,14]$. Analyze and review land use land cover changes are very important for policymaking to improve the qua lity of environmental services.

This study aims to analyze land use land cover change in the catchment area of Musi Hydropower Plant in Bengkulu Province.

\section{Material and Methods}

\subsection{Research location}

The research location was in the catchment area of Musi Hydropower Plant, lies on Rejang Lebong and Kepahiang Regency, Bengkulu Province, Indonesia. The site is at $102^{\circ} 22^{\prime} 18$ .98 " - 102 $32^{\circ} 38.93^{\prime \prime}$ Lat., and $3^{\circ} 16^{\prime} 28.873$ "- $3^{\circ} 33^{\prime} 57.441 "$ long (Figure 1).

\subsection{Data Collection}

The data used in this research is land use land cover map year2000 to 2018 from Ministry of Environment and Forestry of the Republic of Indonesia. There are 11 types of land use land cover, primary dry land forest, secondary dry land forest, plantation forest, dry shrub, estate crops, settlement areas, bare ground/bare soils, water, dry land agriculture, mixed dry land a griculture and paddy fields. 


\subsection{Data Analysis}

The analyse was done by overlaying time series map of land use land cover map from 2000 to 2018 on the map of forest area (Fig. 2). Overlay ana lysis wa s conducted with Geographical Information System tool, ArcMap 10.8.1.

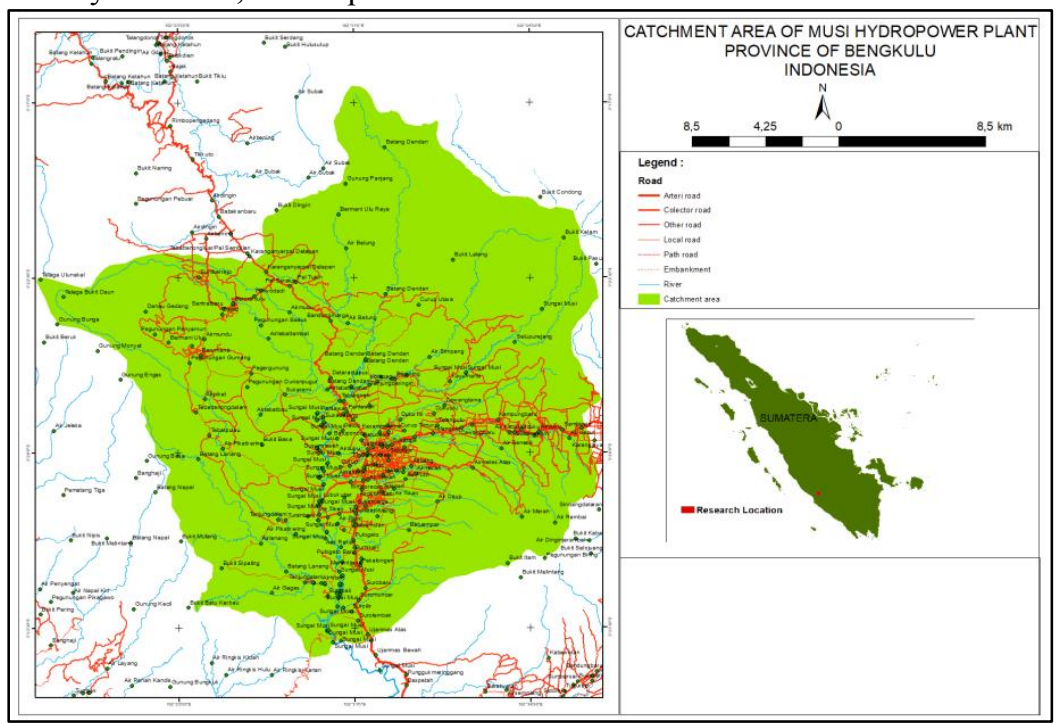

Fig. 1. Research location of Musi Hydropower Plant, Bengkulu Province, Indonesia

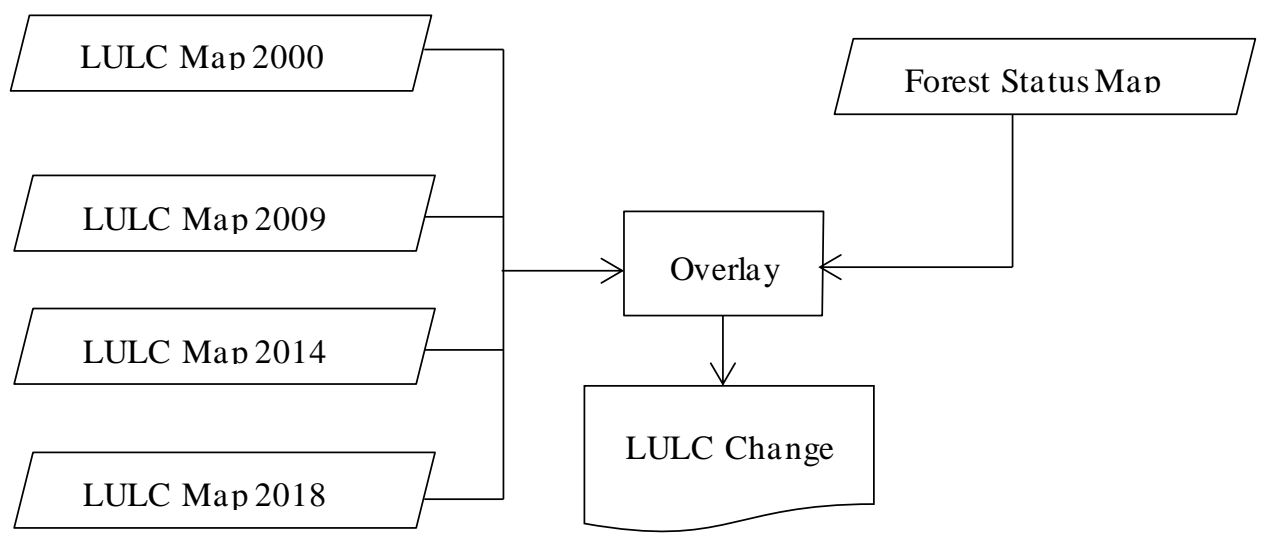

Fig. 2. Research Methodology 


\section{Results and discussions}

\subsection{Land use land cover change}

The result shows that from year $2000-2018$, primary dry land forest decrease significantly, around 568 ha. Primary dry land forest is very important area. Degradation of the area have significant impacts on environmental services, such as losses of biodiversity, losses of carbon storage, increasing soil erosion rates and suspended sediment yields, and increasing the potential of floods on the Musi river. Primary dry land forest degradation followed by degradation of plantation forest, $232 \mathrm{ha}$. Although losses of mixed dry land a griculture higher than primary dry land forest, in the context of environmental services, losses of primary dry land forest more crucial than mixed dry land agriculture. In the other site, settlement areas increasing significantly, around $1.331 \mathrm{ha}$, followed by estate crops, paddy fields, bare ground/bare soils, secondary dry land forest, dry shrub, and dry land agriculture (Table 1, Figure 3-4).

Table 1 and Figure 3 showed that the primary dry land forest and plantation forest in the catchment area of Musi Hydropower Plant tend to decrease yearly. The primary dry land forest, usually convers to secondary dry land forest, dry shrub and mixed dry land a griculture. The area of land use types secondary dry land forest, dry shrub, bare soils, and mixed dry land agriculture fluctuated. The fluctuation showed the dynamics of land use land cover change on the area.

Table 1. Land use land cover the catchment area of Musi Hydropower Plant 2000 - 2018

\begin{tabular}{|c|c|c|c|c|c|c|}
\hline \multirow[t]{2}{*}{ No } & \multirow{2}{*}{$\begin{array}{c}\text { Land Use/Land } \\
\text { Cover }\end{array}$} & 2000 & 2009 & 2014 & 2018 & $\begin{array}{c}\Delta(2000- \\
2018)\end{array}$ \\
\hline & & \multicolumn{5}{|c|}{ Area (ha) } \\
\hline 1 & $\begin{array}{l}\text { Primary dryland } \\
\text { forest }\end{array}$ & $9.951,2$ & $9.583,5$ & $9.547,7$ & $9.383,4$ & $-567,8$ \\
\hline 2 & $\begin{array}{l}\text { Secondary } \\
\text { dryland forest }\end{array}$ & $6.208,7$ & $6.377,0$ & $5.918,4$ & $6.287,2$ & 78,5 \\
\hline 3 & Plantation forest & 412,9 & 412,9 & 375,0 & 180,9 & $-232,0$ \\
\hline 4 & Dry shrub & 259,5 & 269,7 & 349,2 & 305,2 & 45,7 \\
\hline 5 & Estate corp & 0,0 & 0,0 & 0,0 & 150,7 & 150,7 \\
\hline 6 & Settlement areas & $2.784,4$ & $2.784,4$ & $2.783,1$ & $4.115,7$ & $1.331,3$ \\
\hline 7 & $\begin{array}{l}\text { Bare ground/bare } \\
\text { soil }\end{array}$ & 48,4 & 48,4 & 152,3 & 154,6 & 106,1 \\
\hline 8 & Water & 7,0 & 7,0 & 7, & 7,0 & $\overline{0,0}$ \\
\hline 9 & $\begin{array}{l}\text { Dryland } \\
\text { agriculture }\end{array}$ & 163,9 & 163,9 & 187,9 & 187,9 & 23,9 \\
\hline 10 & $\begin{array}{l}\text { Mixed dryland } \\
\text { agriculture }\end{array}$ & $39.156,0$ & $39.345,3$ & $39.671,5$ & $38.077,5$ & $-1.078,4$ \\
\hline 11 & Paddy field & $1.624,3$ & $1.624,3$ & $1.624,3$ & $1.766,4$ & 142,1 \\
\hline & Total & $60.616,4$ & $60.616,4$ & $60.616,4$ & $60.616,4$ & \\
\hline
\end{tabular}




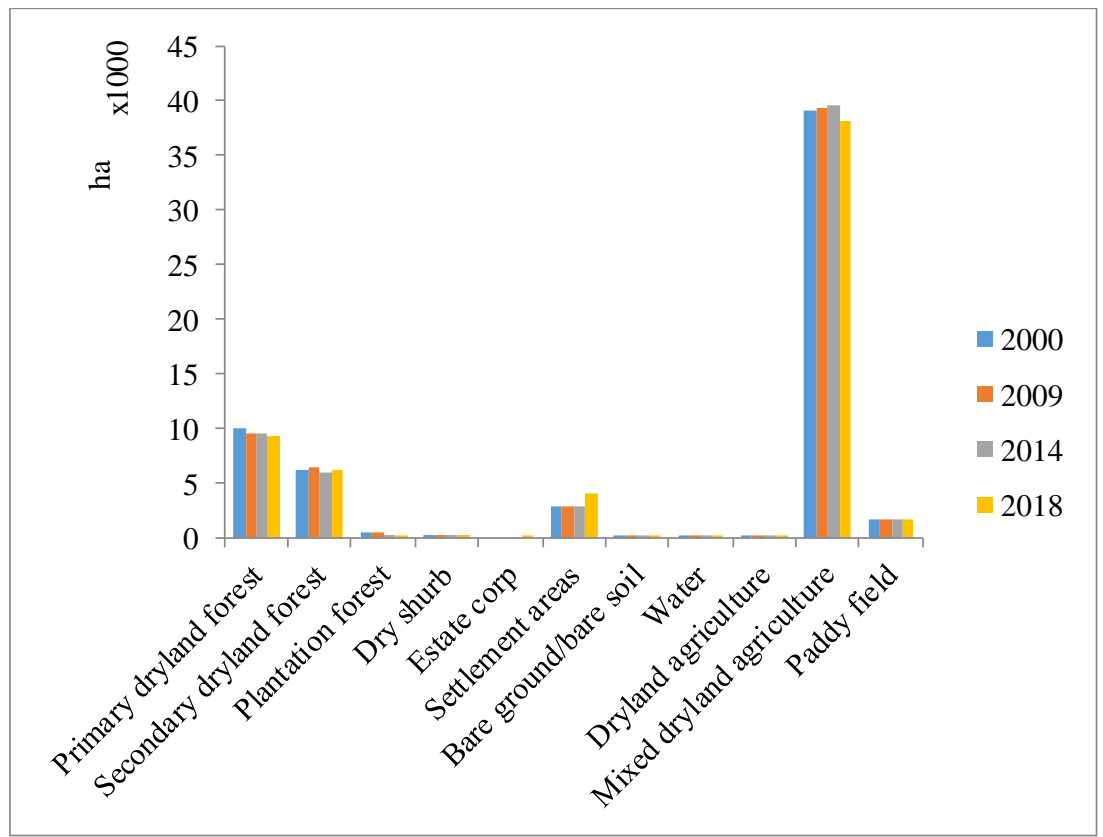

Fig. 3. Land use land cover map of the catchment area of Musi Hydropower Plant $2000-2018$
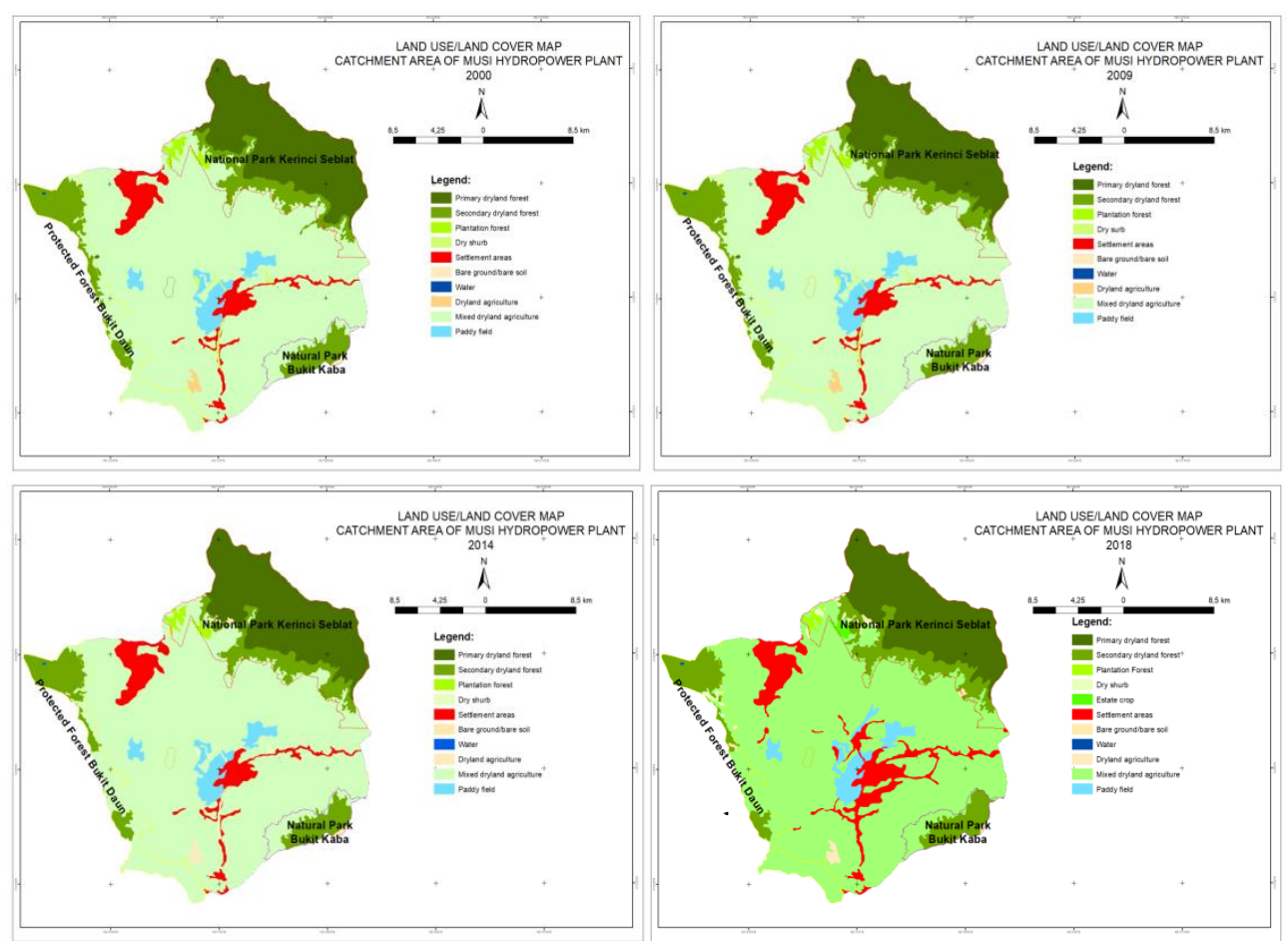

Fig. 4. Land use land cover map the catchment area of Musi Hydropower Plant year 2000-2018

Based on the forest status, there are three main forest area in the catchment area of Musi Hydropower Plant, Protected Forest Bukit Daun (4.985 ha), National Park Kerinci Seblat 
(13.915 ha), and NaturalTourism Park Bukit Kaba (2.355 ha) (Figure 4 and Table 2). At the Protetcted Forest Bukit Daun, the secondary dry land forest tend to decrease, from 2.331,2 ha in 2000 to $1.998,4$ ha in 2018 . In the other site, mixed dry land agriculture tend to increase, from $2.558,3$ ha in 2000 to $2.842,1$ ha in 2018 . It's showed that the forest area convers to agricultural activity (deforestation).

At the National Park Kerinci Seblat, forest area (primary and secondary dry land forest) dominated the area. The primary dry land forest increa se significantly, from $2.353,9$ ha in 2000 to $8.795,3$ ha in 2018 . Secondary dry land forest also increase, from 533,9 ha in 2000 to $2.708,2$ ha in 2018 . In the other site, mixed dry land a griculture decrease significantly from $10.567,5$ ha in 2000 to $1.841,4$ ha in 2018. National Park Kerinci Seblat established in 1999. Increasing the forest area and decreasing mixed dry land agriculture showed that establishment of the area as conservation area effective in preserve the forest area.

At the NaturalTourism Park, secondary dry land forest increase from 1.383,2 ha in 2000 to $1.514,6$ ha in 2018 . In the other site, mixed dry land a griculture decrease from 922,8 ha in 2000 to 814,4 ha in 2018 . Dry shrub and bare ground/bare soil also decrease.

There are so many reason land use conversion on the area, such as economic, anthropogenic, and biophysics factors $[15,16]$. Recently, farmer on the area cultivate fruit crops such as orange and a vocado crops that more valuable than coffee. They are also convers their cultivation culture from monoculture to mixed/intercropping/integrated agriculture, such as intercropping orange with vegetable/horticulture crop, or integrated their a gricultural plantation with tourism (agro-tourism). However, the mixed dry land agriculture on the area still dominated by coffee as the main crops (Table 2).

Table 2. Land use land cover the catchment area of Musi Hydropower Plant 2000 - 2018 based on forest status

\begin{tabular}{|c|c|c|c|c|c|c|c|}
\hline \multirow{2}{*}{ No } & \multirow{2}{*}{$\begin{array}{l}\text { Forest } \\
\text { status }\end{array}$} & \multirow{2}{*}{$\begin{array}{l}\text { Land use land } \\
\text { cover }\end{array}$} & 2000 & 2009 & 2014 & 2018 & $\begin{array}{c}\Delta(2000- \\
2018) \\
\end{array}$ \\
\hline & & & \multicolumn{5}{|c|}{ Area (ha) } \\
\hline 1 & $\begin{array}{l}\text { Nature } \\
\text { Preserves }\end{array}$ & $\begin{array}{l}\text { Mixed dryland } \\
\text { agriculture }\end{array}$ & 0,6 & 0,6 & 0,6 & 0,6 & 0,0 \\
\hline \multirow{8}{*}{2} & \multirow{8}{*}{ 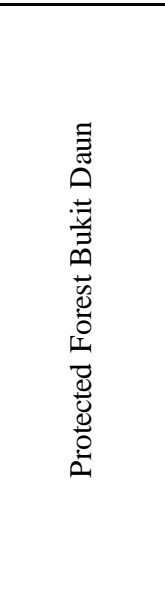 } & $\begin{array}{l}\text { Primary dryland } \\
\text { forest }\end{array}$ & 0,6 & 0,6 & 0,0 & 0,0 & $-0,6$ \\
\hline & & $\begin{array}{l}\text { Secondary } \\
\text { dryland forest }\end{array}$ & $2.331,2$ & $2.331,2$ & $2.106,6$ & $1.998,4$ & $-332,7$ \\
\hline & & Dry shrub & 1,3 & 1,3 & 24,8 & 110,4 & 109,1 \\
\hline & & Settlement areas & 92,3 & 1,3 & 1,3 & 1,3 & $-91,0$ \\
\hline & & $\begin{array}{l}\text { Bare ground/bare } \\
\text { soil }\end{array}$ & 0,0 & 0,0 & 8,4 & 25,2 & 25,2 \\
\hline & & Water & 1,3 & 7,0 & 7,0 & 7,0 & 5,8 \\
\hline & & $\begin{array}{l}\text { Dryland } \\
\text { agriculture }\end{array}$ & 0,0 & 0,0 & 0,6 & 0,6 & 0,6 \\
\hline & & $\begin{array}{l}\text { Mixed dryland } \\
\text { agriculture }\end{array}$ & $2.558,3$ & 2643,6 & 2836,3 & 2842,1 & 283,7 \\
\hline 3 & $\begin{array}{l}\text { Limited } \\
\text { production } \\
\text { forest }\end{array}$ & $\begin{array}{l}\text { Mixed dryland } \\
\text { agriculture }\end{array}$ & 125,4 & 125,4 & 125,4 & 125,4 & 0,0 \\
\hline 4 & 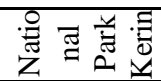 & $\begin{array}{l}\text { Primary dryland } \\
\text { forest }\end{array}$ & $2.353,9$ & $8.983,1$ & $8.959,7$ & $8.795,3$ & $6.441,5$ \\
\hline
\end{tabular}




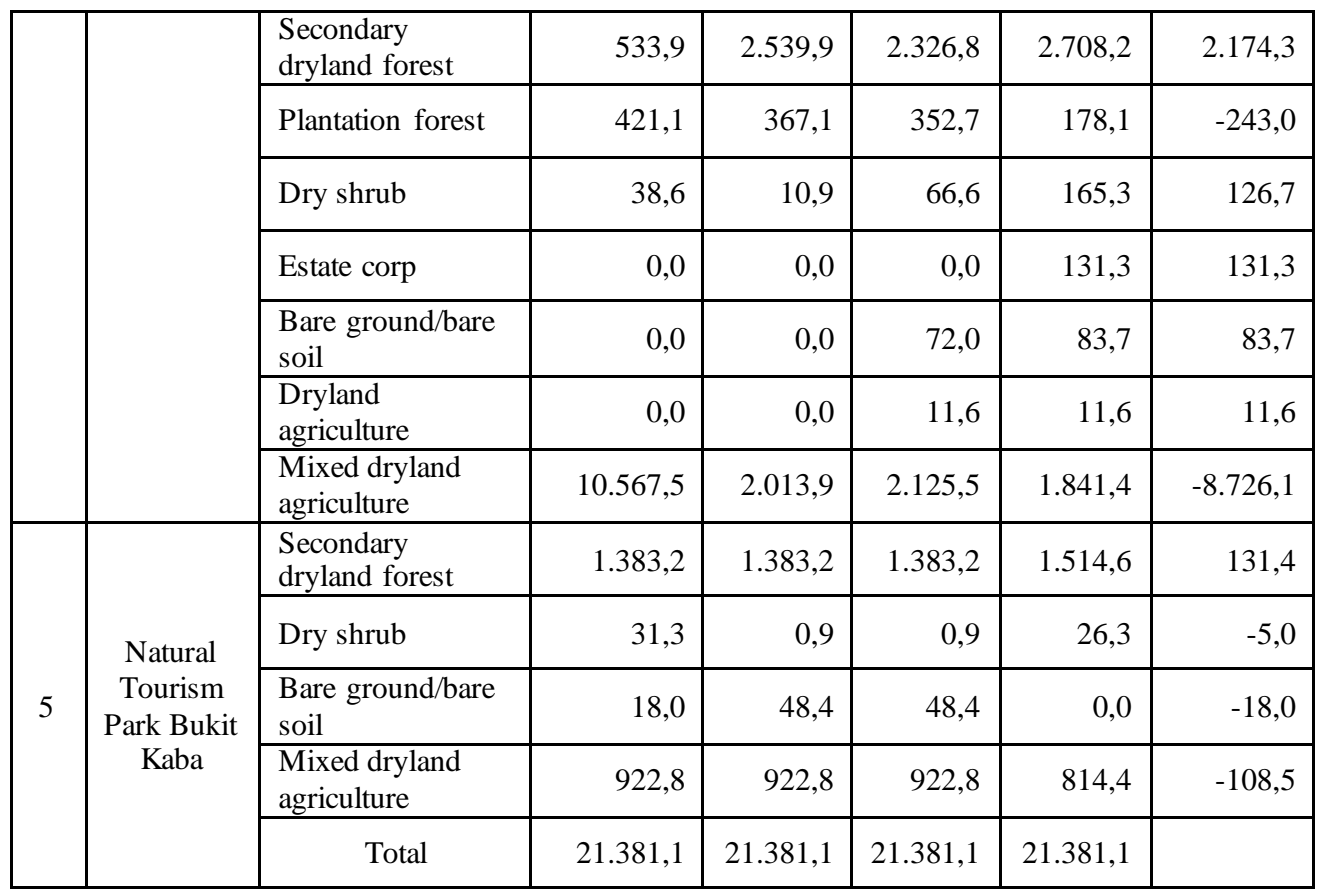

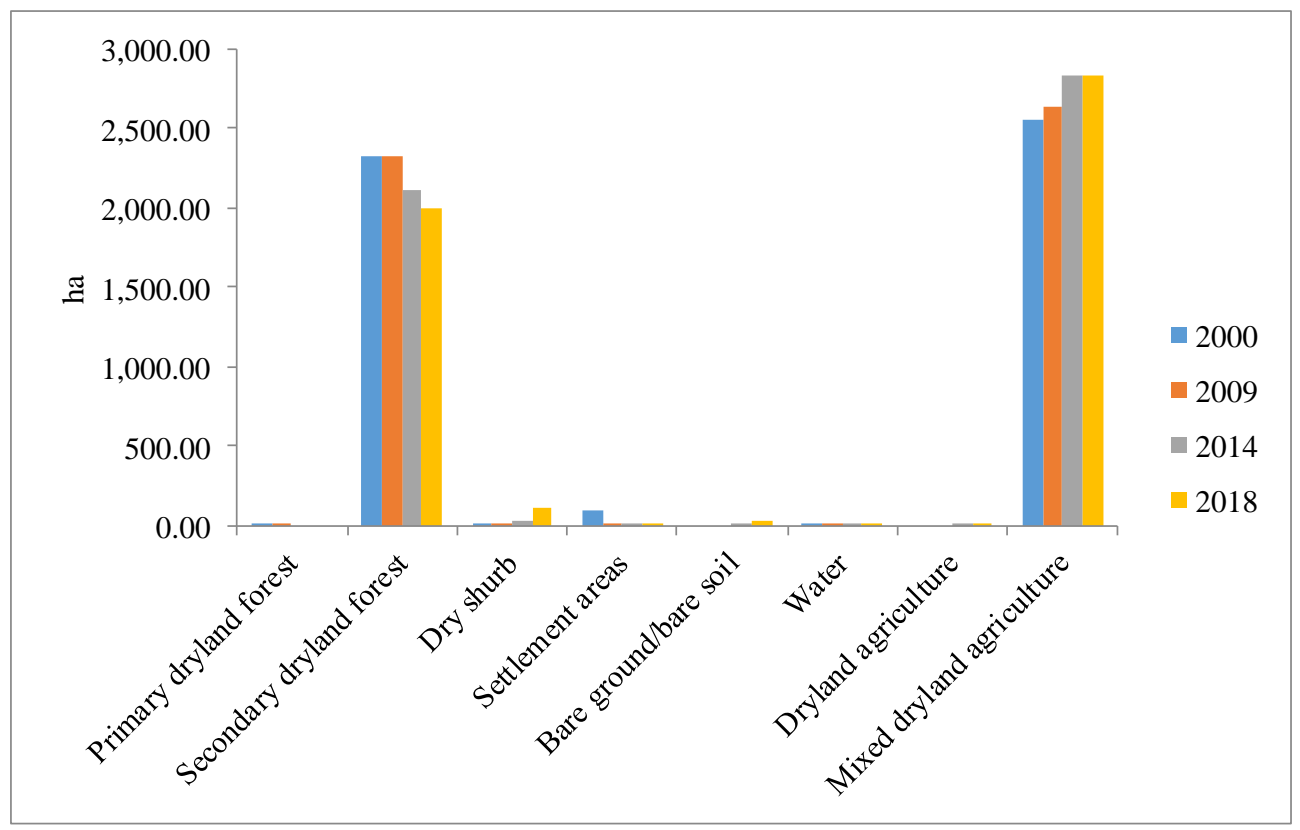

Fig. 5. Land use land cover the catchment area of Musi Hydropower Plant on the Protected Forest Hutan Lindung Bukit Daun 


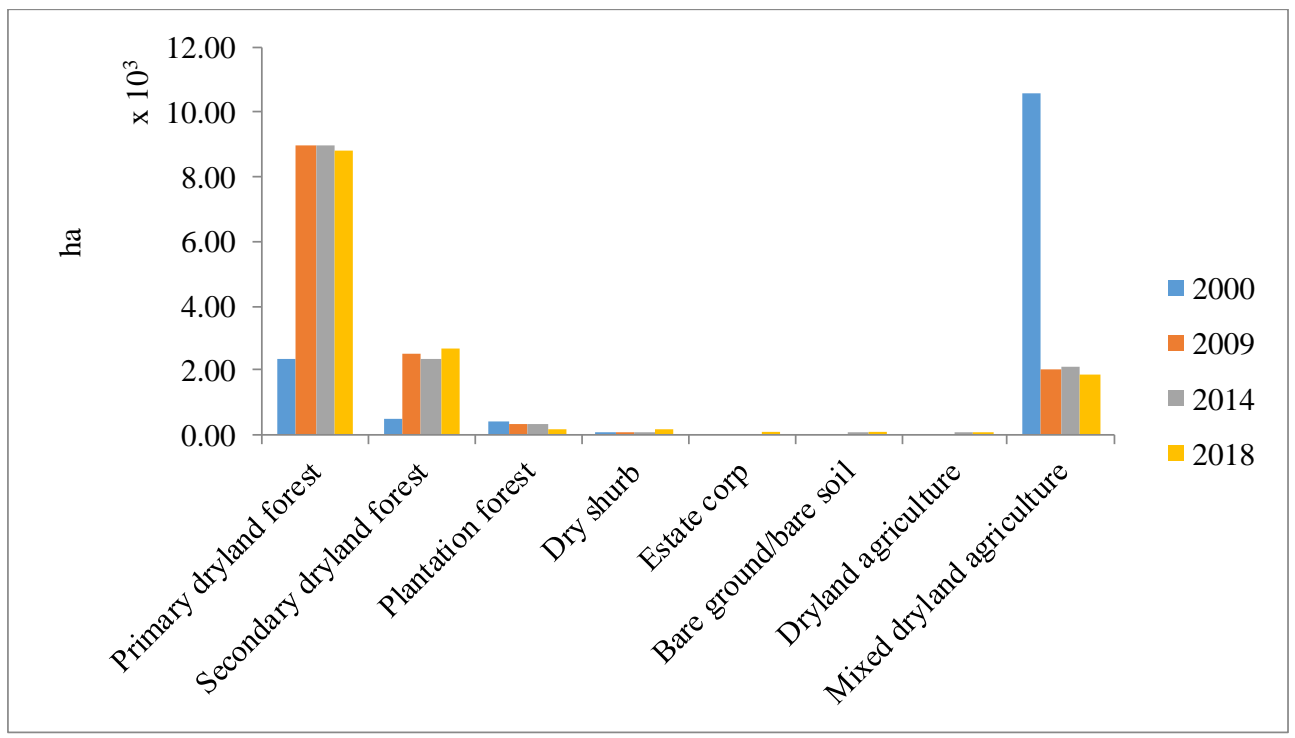

Fig. 6. Land use land cover the catchment area of Musi Hydropower Plant on the National Park Taman Nasional Kerinci Seblat

\subsection{Environmental Issues}

As seen on the Figure 5-6, forest area (primary and secondary dry land forest) tends to decrea se yearly. It shows that deforestation is the main problem on the area. In general, forest area convers to mixed dry land agriculture. The area of mixed dry land agriculture tends to increase yearly. Economic factors is the main driving factor of land use land cover change. People preferred to convert their land to the more valuable commodity.

Land use land cover changes on the catchment area have negative impact on the quality of environmental services, such as erosion and sedimentation on the reservoir of Musi Hydropower Plant. However, farmer tends to ignore the impact of their activity to the environment. Intervention needed to reduce the negative impact of the land use change on ecosystem services.

\section{Conclusions}

Forest area in the catchment area of Musi Hydropower Plant degradated significantly, around 568 ha less than 20 years. Economic factors as the main driving factor of land use land cover change. Land use land cover changes on the catchment area have negative impact on the quality of environmental services, such as erosion and sedimentation on the reservoir of Musi Hydropower Plant. Intervention needed to reduce the negative impact of the land use change on ecosystem services.

\section{References}

1. Y. Liu, F. Yamauchi. Food Policy. 48:182 - 193(2014). ttp://dx.doi.org/10.1016/j.foodpol.2014.05.003 
2. G. Metternicht. Land Use and Spatial Planning. Enabling Sustainable Management of Land Resources. SpringerBriefs in Earth Sciences. Switzerland, CH (2018). P.1-6. https://doi.org/10.1007/978-3-319-71861-3.

3. H. Komiyama. Beyond the limits to growth. New ideas for sustainability from Japan. Springer Open. Tokyo, JP (2014).

4. H. Briassoulis. Analysis of Land Use Change: Theoretical and Modeling Approaches. 2nd edn. Edited by Scott Loveridge and Randall Jackson. WVU Research Repository, Virginia,US (2020).

5. X.Hu, J.S. Næss, C.M. Iordan, Bo Huang, F. Cherubini. Anthropocene. xxx (100291):113(2020). http://dx.doi.org/10.1016/j.ancene.2021.100291.

6. J.A. Verstegen, C. van der Laan, S.C. Dekker, A.P.C. Faaij, M. J. Santos. Ecological Indica tors. 103:563-575(2019). https://doi.org/10.1016/j.ecolind.2019.04.053.

7. S.D. Tarigan. Procedia EnvironmentalSciences. 33:386-392(2016).

8. K. Amri, A.N. Halim, Ngudiantoro, M.F. Barchia.. APCBEE Procedia. 10: 235 240(2014).

9. K. Amri, A.N. Halim, Ngudiantoro, M.F. Barchia.. IPCBEE Procedia. 63: 83 - 87(2014).

10.A.M. Messina, T.W. Biggs. Journal of Hydrology. 538:726 - 742(2016). http://dx.doi.org/10.1016/j.jhydrol.2016.03.053.

11.P.N. Owens, A.J. Collins. Soil Erosion and Sediment Redistribution in River Catchments. Measurement, Modeling, and Management. www.Cabi.Org. Oxfordshire, UK (2006).

12.A. van Soesbergen. A Review of Land Use Change Models. UNEP World Conservation Services. Cambridge, UK (2016).

13. You Chang, Khang Hou, Xuxiang Li, Yunwei Zhang, Pei Chen. IOP Conf. Ser.: Earth Environ. Sci. 113:012087 (2018).

14.C. Agarwal,Glen M. Green, J. M. Grove, Tom P Evans, Charles M. Schweik. A Review and Assessment of Land Use Change Models: Dynamics of Space, Time and Human Choise. USDA. Washington, US (2001).

15.H. Haberl. Ecological Economics. 119:424 - 431(2015). http://dx.doi.org/10.1016/j.ecolecon.2014.10.002.

16.D. Djaenudin, R. Oktaviani, S. Hartoyo, H. Dwiprabowo. Procedia Environmental Sciences. 33:78-86 (2016). 